\title{
Peningkatan Kemampuan Perpajakan Rumah Sakit Bagi Pegawai Rumah Sakit Permata Pamulang Melalui Pelatihan Perpajakan
}

\author{
Agustine Dwianika ${ }^{1}$, Hastuti Naibaho ${ }^{2}$ \\ Universitas Pembangunan Jaya \\ 1agustine.dwianika@upj.ac.id \\ 2hastuti.naibaho@upj.ac.id
}

\begin{abstract}
Perbedaan persepsi pegawai keuangan rumah sakit tentang perlakuan pajak rumah sakit antar berbagai divisi menimbulkan polemik tersendiri, terutama terkait pengenaan Pajak Pertambahan Nilai $(P P N)$. Pertanyaan yang sering timbul adalah apakah jasa rumah sakit dikenai PPN ataukah tidak serta bagaimana perlakuan perpajakan yang sesuai dengan aturan di Indonesia. Kemampuan karyawan dalam perpajakan menjadi sangat penting agar tidak terjadi kesalahan perhitungan dan pelaporan pajak yang berakibat harus dibayarnya sanksi administratif ataupun denda perpajakan. Hal ini dipahami dengan baik oleh manajemen Rumah Sakit Permata Pamulang, mereka serius memperbaiki kemampuan manajemen dari waktu ke waktu agar lebih baik dan lebih efisien, termasuk dalam hal manajemen perpajakan. Berdasarkan permasalah tersebut Universitas Pembangunan Jaya melakukan kegiatan pengabdian masyarakat berupa Seminar Perpajakan Rumah Sakit dengan tujuan untuk membantu seluruh karyawan rumah sakit tersebut memahami perlakuan pajak dengan benar. Seminar tersebut membahas lebih lanjut kaitan transaksi yang sering terjadi di rumah sakit dengan terhutang pajak yang timbul atas transaksi tersebut seperti pembayaran dokter, sewa alat laboratorium, transaksi obat dan yang lainnya. Pembahasan mengenai perlakuan PPN untuk transaksi rawat inap dan rawat jalan tidak sama, begitupun perlakuan untuk biaya berobat bagi keluarga yang kurang mampu tidak dapat disamakan. Pengetahuan perpajakan yang cukup diperlukan oleh semua pihak terkait, semakin akurat pelaporan pajak maka semakin kecil risiko kesalahan pajak perusahaan. Pada akhir sesi kegiatan pengabdian masyarakat, tim melakukan evaluasi atas pemahaman peserta terkait perpajakan rumah sakit. Hasil perbandingan sebelum dan sesudah mereka mengikuti kegiatan seminar ini menunjukkan perubahan yang signifikan, dari sebelumnya tidak terlalu paham dan mampu menghitung transaksi yang terkait perpajakan rumah sakit, menjadi mengerti perlakuan perpajakan rumah sakit secara umum dengan baik.
\end{abstract}

\section{Keywords: Evaluasi, Kemampuan Perpajakan, Pelatihan Perpajakan, dan Perpajakan Rumah Sakit.}

\section{PENDAHULUAN}

Perbedaan perlakuan pajak untuk transaksi rumah sakit seringkali terjadi di beberapa kasus yang ada lapangan. Dalam pasal 20 Undang-undang Rumah Sakit No. 44 tahun 2009 (www.depkes.go.id), Rumah Sakit (RS) dibedakan menjadi Rumah Sakit Publik yang pengelolaannya dilakukan oleh pemerintah, pemerintah daerah dan badan hukum yang bersifat nirlaba, dan Rumah Sakit Privat yang biasanya dikelola oleh badan hukum dengan tujuan mendapatkan keuntungan yang berbentuk Perseroan Terbatas (PT) atau Persero. Dalam ketentuan bentuk usaha nirlaba memang RS tetap dituntut untuk dapat menjaga standard mutu pelayanan kesehatan sebagai acuan dalam melayani pasiennya. Sehingga membutuhkan sarana serta prasarana serta tenaga profesional yang sesuai dengan standar.

Dari perspektif pembiayaan, RS Publik yang bersifat nirlaba mendapatkan sumber dana dari anggaran pemerintah atau pemerintah daerah, selain pendapatan dari kegiatan rumah sakit itu sendiri. Berbeda dengan RS Privat yang sangat 
mengandalkan pemerimaan dari kegiatan operasional rumah sakit, oleh karenanya RS Privat harus mengoptimalkan semua aspek keuangan termasuk memanfaatkan insentif pajak. Seperti yang tertuang pada UU RS pasal 30 ayat 1.h, yang menyatakan bahwa RS pendidikan mendapat insentif pajak yang lebih lanjut akan diatur dengan peraturan permerintah (PP).

Selain pemanfaatan insentif pajak tersebut, manajemen RS privat harus cermat dalam mengangani permasalahan pajaknya. Memastikan setiap transaksi terhutang pajak terhitung dengan benar, melakukan audit internal maupun eksternal baik laporan keuangan maupun laporan perpajakan. Menurut informasi dari manajemen RS Permata Pamulang Ciputat, kadang kala terdapat beberapa kendala dalam perlakuan PPN dikarenakan belum meratanya sosialisasi perpajakan disemua bagian dalam organisasi. Transaksi pengenaan PPN tidak hanya menjadi tanggungjawab bagian keuangan ataupun pajak saja, namun akan lebih baik jika semua lini memahaminya, termasuk kasir dan bagian pendaftaran. Hal ini dianggap penting bagi manajemen RS Permata Pamulang agar proses pelaporan perpajakan berjalan baik tanpa kesalahan, sehingga tidak timbul sanksi administratif ataupun denda keterlambatan yang ditimbulkan dari kesalahan lapor pajak.

Kegiatan seminar perpajakan rumah sakit yang mengundang dosen UPJ sebagai nara sumber ini bertujuan agar semua karyawan di RS Permata Pamulang berkesempatan mendapatkan gambaran besar pentingnya memperhatikan aspek perpajakan di semua transaksi, sehingga mendapatkan pemahaman yang baik dan meningkatkan kesadaran pajak. Karena kesalahan satu pihak saja, dapat berakibat potensi pengeluaran pajak yang tidak efisien. Diharapkan seluruh peserta seminar dapat mendiskusikan dan berlatih soal-soal perpajakan secara umum yang sering terjadi di rumah sakit, dan berkonsultasi tentang kendala perhitungan pajak yang dihadapi. Sehingga kedepannya peserta mampu menghitung besarnya terhutang pajak yang timbul atas transaksi terhutang pajak di rumah sakit.

\section{METODE PELAKSANAAN}

Sehubungan dengan kegiatan pengabdian masyarakat pada RS Permata Pamulang, maka tim pelaksana melakukan tahapan sebagai berikut: Pertama,Tim pelaksana berkoordinasi dengan manajemen RS Permata Pamulang terkait jenis kebutuhan pelatihan yang tepat bagi karyawannya. Kedua, tim pelaksana memastikan bahwa peserta yang mengikuti pelatihan tersebut memiliki keterkaitan dengan aspek perpajakan rumah sakit. Ketiga, melakukan pre-test terkait tingkat pemahaman peserta. Keempat, seminar, latihan soal perhitungan pajak rumah sakit dan diskusi. Kelima, evaluasi kemampuan perpajakan peserta dengan melakukan post-test.

\section{GAMBARAN SINGKAT KEGIATAN PENGABDIAN MASYARAKAT}

Kegiatan pengabdian masyarakat ini dilakukan pada Selasa, 13 November 2018 bertempat di Aula Lantai 5, RS Permata Pamulang dari pukul 08.00 sampai dengan 17.00 WIB. Diawali dengan penandatanganan nota kesepahaman kerjasama antara perguruan tinggi dan pihak manajemen RS Pemata Pamulang. Tujuannya adalah agar keberlangsungan kerjasama dan kegiatan pengabdian rumah sakit serupa dapat terus berlanjut dikemudian hari. Kemudian disusul dengan menyebarkan kuisioner pre-post kegiatan untuk memastikan seberapa paham peserta terhadap peraturan perpajakan rumah sakit yang berlaku di Indonesia. Acara inti adalah seminar perpajakan rumah sakit yang diikuti oleh 30 orang peserta dari semua lini manajemen RS Permata Pamulang yang sering kali terkait dalam proses transaksi 
yang terjadi dan berpotensi menimbulkan hutang pajak. Peserta tersebut diajukan oleh pihak manajemen RS Permata Pamulang, mereka melakukan penyaringan karyawan yang memang mampu mengikuti seminar tersebut dan seringkali berhubungan dengan pasien, dokter, audit eksternal dan bagian lainnya yang memungkinkan terkait dengan kegiatan atau transaksi yang berpotensi terhutang pajak.

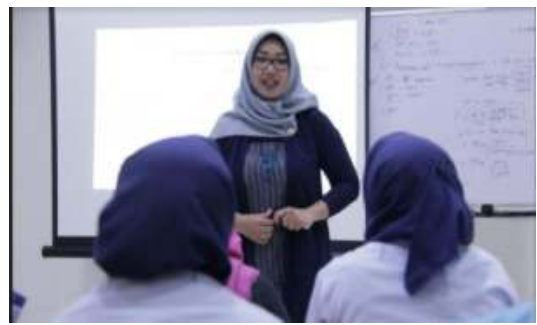

Gambar 1. Nara Sumber Ibu Agustine Memberikan Materi

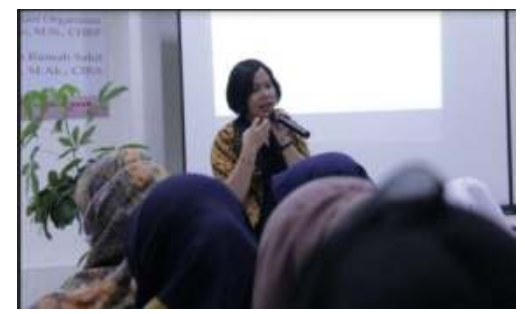

Gambar 2. Nara Sumber Ibu Dr. Hastuti Memberikan Materi

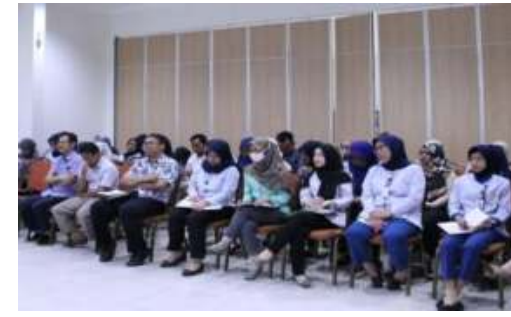

Gambar 3. Seminar diikuti oleh karyawan RS Permata Pamulang

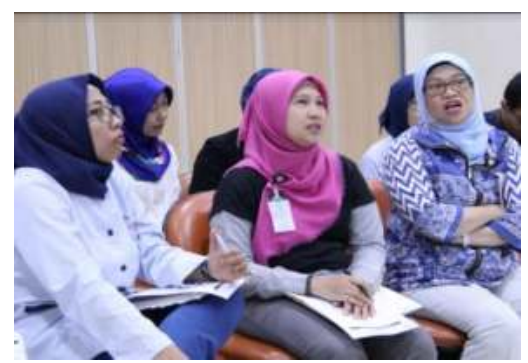

Gambar 4. Peserta dalam Diskusi Interaktif

\section{HASIL DAN PEMBAHASAN}

Program pengabdian masyarakat dalam bentuk seminar perpajakan rumah sakit ini berjalan selama satu hari kerja penuh. Di awal kegiatan tim pelaksanan kegiatan pengabdian masyarakat memberikan kuisioner kepada seluruh peserta untuk mengukur pengetahuan perpajakan rumah sakit secara umum, termasuk terkait PPN. Dari hasil pre-test tersebut didapatkan hasil bahwa $30 \%$ peserta mengetahui perpajakan rumah sakit, dan $70 \%$ belum mengetahui secara pasti. Setelah itu tim melakukan seminar dan pelatihan perpajakan rumah sakit selama sehari penuh dan kemudian melakukan post-test untuk pengukuran yang sama.

Dari hasil pengolahan data kuisioner yang disebarkan untuk kedua kalinya setelah melakukan pelatihan, diperoleh data bahwa $90 \%$ peserta telah memahami perpajakan rumah sakit secara umum, dan $10 \%$ belum terlalu paham. Jika dibandingkan antara data pre-test dan posttest tersebut, maka didapatkan kenaikan dari $30 \%$ menjadi $90 \%$.

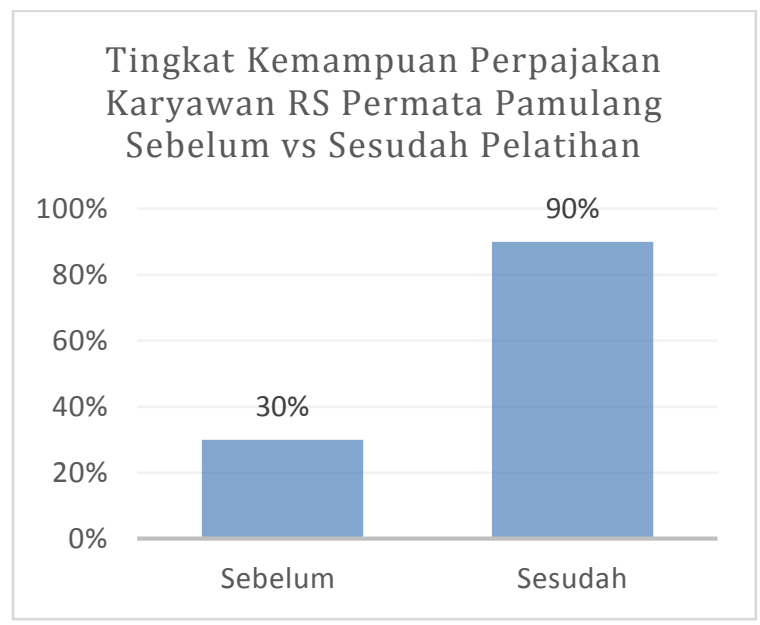

Sumber: Data yang diolah (2019)

\section{KESIMPULAN DAN SARAN}

Kegiatan pengabdian masyarakat yang berjudul " Peningkatan Kemampuan Perpajakan Rumah Sakit Bagi Pegawai 
Rumah Sakit Permata Pamulang Melalui Pelatihan Perpajakan" berjalan dengan baik dan mendapatkan apresiasi dari pihak manajemen RS Permata Pamulang. Kegiatan ini dapat memberikan output sebagai berikut: 1). Meningkatnya pengetahuan perpajakan rumah sakit karyawan RS Permata Pamulang dari yang semula sebesar 30\%, menjadi 90\%. 2). Terdapat materi pelatihan berupa contoh soal dan kasus perpajakan rumah sakit yang dapat digunakan baik oleh internal karyawan RS Permata Pamulang maupun khalayak umum.

Kegiatan ini juga memiliki beberapa kekurangan diataranya: 1). Keseluruhan peserta merupakan karyawan dari RS Permata Pamulang, sehingga pengetahuan yang didapatkan hanya dari satu sisi saja. 2). Waktu kegiatan yang hanya dilakukan 1 (satu) hari, sehingga belum keseluruhan materi terkait perpajakan rumah sakit sampai dengan pembuatan SPT dilakukan. Oleh karenanya, tim pelaksana pengabdian masyarakat ini mengusulkan saran berikut: 1). Dapat pula melibatkan peserta di luar karyawan RS Permata Pamulang seperti, staff rekan sesama RS yang sering berhubungan dalam transaksi yang berpotensi terhutang pajak seperti vendor, dokter maupun pasien. Sehingga didapatkan pemahanan secara luas dan merata dari perspektif RS maupun pelanggan. 2). Waktu penyelenggaraan yang lebih lama, sehingga dapat dilakukan pembahasan materi lebih banyak dan paripurna. Bahkan diharapkan bisa sampai dengan pelaporan SPT.

\section{UCAPAN TERIMA KASIH}

Tim Pelaksana Pengabdian Masyarakat mengucapkan terima kasih kepada seluruh pihak yang terlibat di dalam kegiatan pengabdian masyarakat ini. Kami sampaikan ucapan terima kasih yang sebesar-besarnya kepada Universitas Pembangunan Jaya, LP2M Universitas
Pembangunan Jaya, maupun manajemen dan karyawan peserta seminar - pelatihan perpajakan rumah sakit dari Rumah Sakit Permata Pamulang.

\section{DAFTAR PUSTAKA}

Trisnantoro, L. 2017. RS Publik : RS Privat di Indonesia.

Republik Indonesia, Undang-Undang Nomor 6 Tahun 1983 sebagaimana telah diubah terakihir dengan Undang-Undang Nomor 28 Tahun 2007 tentang Ketentuan Umum dan Tata Cara Perpajakan.

Republik Indonesia, Undang-Undang Nomor 36 Tahun 2008 Tentang Perubahan Keempat Atas UndangUndang Nomor 7 Tahun 1983 Tentang Pajak Penghasilan.

Republik Indonesia, Keputusan Direktur Jenderal Pajak Nomor KEP536/PJ./2000 Tentang Norma Penghitungan Penghasilan Netto dan Tata Cara Pembuatan Catatan Bagi Wajib Pajak Yang Dapat Menghitung Penhasilan Netto dengan Mengunakan Norma Penghitungan Pajak Penghasilan.

http://www.depkes.go.id/

$\underline{\text { http://pajak.go.id }}$

https://rspermatapamulang.co.id/ 